\title{
Psychometric Properties of Social Media and Academic Influence Scale (SMAIS) Using Exploratory Factor Analysis
}

\author{
Ahmad Abdullahi Ibrahim, Rabiu Garba Idris, and A'isha Hassan Sulaiman
}

\begin{abstract}
The paper presents validation study to determine psychometric adequacy of a measure of Social Media on Academic Attainment among university students. A sample of 200 undergraduate students from Northwest University, Kano was drawn through random sampling. The internal consistency index of the measure was found satisfactory with 0.76 . Moreover, the instrument demonstrates acceptable psychometric properties and four distinct factors that reflect the influence of social media on academic attainment with access to social media trust being the most important. The Exploratory Factor Analysis identified four factors labeled as 'access to social media', 'academic communication', 'exposure' and 'academic attainment' explaining $24.11 \%, 13.50 \%, 10.30 \%$ and 8.69\% of the variances respectively. Moreover, the instrument demonstrates factorial validity, construct validity and structure of measures of constructs and the four factor solution explains $56.61 \%$ total of variance.
\end{abstract}

Index Terms-Social media, academic attainment, construct, validation, KMO, variance, exploratory factor analysis.

\section{INTRODUCTION}

Social media is one of the most influential means of communications in the present days. A number of social networking sites exist facilitates communication among people regardless of the distance, making it simple for people to share information, files, pictures and video as well as creating blogs and sending instant messages as well as conducting real time conversations. These systems are considered as social media as they allow easy and effective communication. Facebook, Whats App and Twitter are among the most useful social network sites in that direction. These sites provide direct communication with other people socially and they are also play crucial and influential role economically and educationally.

The deriving factor for adopting social media in education is the ease of their accessibility, convenience, functionality, and flexibility [1]. Many studies such as [2], [3] show that the use of social media in teaching support social constructivist techniques to learning, they potentially improve students' construction of understanding and promote students' level of interaction with each other. It is evident that social media are important platform for knowledge sharing among learners and

Manuscript received June 2, 2015; revised September 23, 2015.

Ahmad Abdullahi Ibrahim and Rabiu Garba Idris are with Faculty of Education International Islamic University, Malaysia (e-mail: ahmad.daneji@yahoo.com).

A'isha Hassan Sulaiman is with Faculty of Education, Northwest University, Kano, Nigeria. also teachers. This makes social media technologies advantageous being available on the internet, free or requires low spending that eliminate potential barrier to access of the technology.

The advantages of social media among students of higher learning have identified comprising of relationship enhancement, improving learning motivation, offering personalize course materials and developing collaborative abilities among students [4]. This means that social media have possibilities for enhancing students' contact thereby improving participation in the course(s) they take. Participation in learning via social media could best help introvert students so that they can learn and function through online group learning with less or no anxiety to raise questions before their colleagues. Therefore, the present study aims to examine psychometric properties of the Social Media and Academic Influence Scale (SMAIS) by determining construct validity of the instrument.

\section{LITERATURE REVIEW}

The rampant use of social Networking Site has become a global phenomenon in this century. This started as hobby for some computer literate people has become a social norm and way of life for people from all over the world [5]. Youths and young adults remarkably accepted these sites as a way to communicate with their peers, share information, reinvent their personalities, and showcase their social lives [5].

Nowadays, teenagers use internet for the most part of their daily activities and information sharing and gathering, unlike previous generation of people whose use of technology was limited to radio and television, [6]. It is revealed that about ninety percent of the teens in the United State have access to internet, and approximately five percent of the teens use internet more than once in a day [7]. This indicates that about half of the teens are not only users of the internet but members of social networking sites, and they use internet for planning and socializing with friend [7].

The use of social network sites is considered as one of the most important factor that can influence academic attainment of students whether positively or negatively. According to [8] social network sites are advantageous to both teachers and students if used as a tool for knowledge creation and dissemination. However, University of New Hampshire revealed that most of students use social media for social connection and entertainment, but they are also using it for educational and professional reasons.

Therefore, an ever drastic increase of the use of Social 
Media among students of higher institutions did not only call for parental and teacher monitoring of students' use of social media, but also attract the attention of academicians and researchers toward this phenomenon. Students' use of social media continues to create challenges and issues for higher education professionals and keeping abreast of these challenges has proved difficulties due to rapid development of technology [9]. [10] Expressed that there is evidence that higher education institutions have taken initiatives in disclosing information about online social networking involvement to their students. For example, Cornell University's online "thought on Facebook", which creates students awareness about responsible use of online social networks. Thus, this study focused on construct validity of the instrument use to examine social media and their relation to students' academic attainment.

\section{Methodology}

Quantitative research designed was employed in this study. Students of Northwest University, Kano were considered as target population of the study. During the time of this research, there were about 2000 undergraduate students for both level one and two. Based on the population, sample size of this study constituted of 200 undergraduate students as suggested by [11]. The sample was drawn through random sampling procedure. 300 questionnaires were distributed among the existing level 1 and 2 students but 200 usable ones were retrieved and used in the analysis. The questionnaire was personally administered by the researcher with help of students' level coordinators for randomization.

\section{A. Instrument of the Study}

In the quantitative research design, questionnaire is the instrument mostly used for data collection [12]. Therefore, the researcher used questionnaire as an instrument for data collection in this study. The questionnaire comprises of two parts. The first part concentrated on the demographic information of the respondents which includes: gender, age, program, level of study, time spend on social media in a day, time spend for study per day, more preferable social network for students, and most visited social networking site, The second part of the questionnaire consists of 19 items which were used to measure students' use of social media and its influence on students' performance. The instrument was design in form of 5 point Likert Scale ranged from 1 Strongly Disagree to 5 Strongly Agree. However, the instrument was adapted from [13].

\section{B. Data Analysis Procedure}

The data was collected and subjected to cleaning, normality and outlier testing. In the second phase, the data was subjected to reliability testing and in the third phase exploratory factor analysis was carried out aimed at identifying the factors and establishing construct validity. As mentioned earlier that the scale at initial stage contained 19 items and in the process of validation four items were dropped leaving behind 14 valid items.

Exploratory Factor Analysis (EFA) was purposely employed to determine the underlying dimensional structure of Social Media and Academic Influence Scale (SMAIS). The data obtained was analyzed using EFA process that provides systematic factorial technique. Varimax Rotation was employed to determine dimensionality of the measure. The items that fail to meet loading requirements were removed for further analysis. Each of the four factors solution identified has satisfactory level of internal consistency and adequacy.

\section{RESUlts}

Descriptive statistics of the respondents shows that majority of the respondents were male accounting for $63.5 \%$ with mean age 1.73 ( $\mathrm{SD}=.73$ ) ranged between $16-25$ years. Most of the respondents were affiliated to faculty of education and social and management science accounting for $35.5 \%$ and $28 \%$ respectively. In terms of the level of study, $67.6 \%$ were in level 200 and about $61.5 \%$ spend 1-2 hours per day on social media. However, $49 \%$ of the respondents have preference of face book, $43.5 \%$ WhatsApp and $7.5 \%$ Twitter. Conversely, $49.5 \%$ use social media for educational purpose, $39.5 \%$ informational and $11 \%$ environmental. Table I gives the summary reports of the participants' demographic information. Table I gives summary of the demographic information of the respondents.

TABLE I: DEMOGRAPHIC PROFILE OF THE RESPONDENTS

\begin{tabular}{|c|c|c|}
\hline Demographic variable & Frequency & Percentage \\
\hline \multicolumn{3}{|l|}{ Gender } \\
\hline Male & 127 & 63.5 \\
\hline Female & 73 & 36.5 \\
\hline \multicolumn{3}{|l|}{ Age } \\
\hline $16-20$ years & 76 & $38 \%$ \\
\hline 21-25 years & 69 & 34.5 \\
\hline Above 25 years & 55 & 27.5 \\
\hline \multicolumn{3}{|l|}{ Faculty } \\
\hline Education & 71 & 35.5 \\
\hline Humanity & 23 & 11.5 \\
\hline Science & 50 & 25 \\
\hline $\begin{array}{l}\text { Social \& Management } \\
\text { Science }\end{array}$ & 56 & 28 \\
\hline \multicolumn{3}{|l|}{$\begin{array}{l}\text { Time spend on media } \\
\text { per day }\end{array}$} \\
\hline 1-2 hours & 123 & 61.5 \\
\hline 2-3 hours & 46 & 23 \\
\hline 3-4 hours & 31 & 15.5 \\
\hline \multicolumn{3}{|l|}{ Preferred social media } \\
\hline Facebook & 98 & 49 \\
\hline Twitter & 15 & 7.5 \\
\hline WhatsApp & 87 & 43.5 \\
\hline \multicolumn{3}{|l|}{$\begin{array}{l}\text { Group subscribe on } \\
\text { social media }\end{array}$} \\
\hline Educational & 99 & 49.5 \\
\hline Environmental & 22 & 11 \\
\hline Informational & 79 & 39.5 \\
\hline
\end{tabular}

\section{A. Exploratory Factor Analysis (AFA) Result}

The result of AFA reveals that most of the items correlated on at least .3 demonstrating absence of Multicollinearity problem. Kaiser-Meyer-Olkin which measures of sampling adequacy was .710, above the recommended value of .5 (Hair 2010, Tabachnick, 2007). The Bartlett's test of sphericity was 
also significant $\left(\chi^{2}(91)=540.033,(p<.05)\right.$. However, the diagonals of the anti-image correlation matrix and the communalities were all over .5 with exception of few items with communalities that ranged between .411 and .498 . The items were retained based on [14] bench mark of .3, confirming that most of the items shared some common variance with other items. Based on the overall indicators, factor analysis was carried out with items 1, 14, 15, 16 and 17deleted having failed to meet the requirements.

There are four factors extracted from the instrument which labeled as 'access to social media', 'academic communication', 'exposure' and 'academic attainment' explaining $24.11 \%, 13.50 \%, 10.30 \%$ and $8.69 \%$ of the variances respectively. Table II elaborates the four factors and reliability of each of the factors. However, the factors had an initial Eigen values that explained $3.376 \%, 1.890 \%$, $1.442 \%$ and 1.218 of the variances. Varimax rotation of the factor loading matrix was used to examine the four factor solution which explained $56.61 \%$ variance.

TABLE II: EXPLORATORY FACTOR ANALYSIS

\begin{tabular}{|c|c|c|c|c|}
\hline Number and name of the Factors & Item Statement & Communalities & Loading & Alpha \\
\hline \multirow[t]{2}{*}{1} & $\begin{array}{l}\text { I access social media via hand } \\
\text { phone, Ipad and computer }\end{array}$ & .617 & .750 & \multirow{5}{*}{.711} \\
\hline & $\begin{array}{l}\text { I upload and download video and } \\
\text { music from social media }\end{array}$ & .505 & .612 & \\
\hline \multirow[t]{2}{*}{ Access To Social Media } & $\begin{array}{l}\text { I post news and pictures on the use } \\
\text { social media }\end{array}$ & .411 & .627 & \\
\hline & $\begin{array}{l}\text { I use social media for blogging, } \\
\text { creating polls, quiz etc }\end{array}$ & .495 & .539 & \\
\hline 2 & $\begin{array}{l}\text { I use social media for academic } \\
\text { chatting with friends and others }\end{array}$ & .586 & .718 & \\
\hline \multirow[t]{3}{*}{ Academic Communication } & $\begin{array}{l}\text { Social media helps me communicate } \\
\text { with my teachers and classmates } \\
\text { about my study }\end{array}$ & 608 & .755 & \multirow[t]{4}{*}{.709} \\
\hline & $\begin{array}{l}\text { Social media influences the way I } \\
\text { speak or write }\end{array}$ & .498 & .413 & \\
\hline & $\begin{array}{l}\text { I use formal language when } \\
\text { communicating with others via } \\
\text { social media }\end{array}$ & .451 & .619 & \\
\hline 3 & $\begin{array}{l}\text { Social media positively affects my } \\
\text { study }\end{array}$ & 600 & .759 & \\
\hline \multirow[t]{2}{*}{ Exposure } & $\begin{array}{l}\text { Social media is platform where is } \\
\text { express my ideas and feelings to } \\
\text { others }\end{array}$ & .588 & .741 & \multirow[t]{3}{*}{.702} \\
\hline & $\begin{array}{l}\text { To some extent social media has } \\
\text { changed my habit }\end{array}$ & .492 & 610 & \\
\hline 4 & $\begin{array}{l}\text { Social media improves my academic } \\
\text { pursuits }\end{array}$ & .519 & .643 & \\
\hline \multirow[t]{2}{*}{ Academic Attainment } & $\begin{array}{l}\text { Social media helps me make my } \\
\text { assignment very well }\end{array}$ & .765 & .856 & \multirow[t]{2}{*}{.704} \\
\hline & $\begin{array}{l}\text { Social media improves my academic } \\
\text { attainments in general }\end{array}$ & .790 & .874 & \\
\hline
\end{tabular}

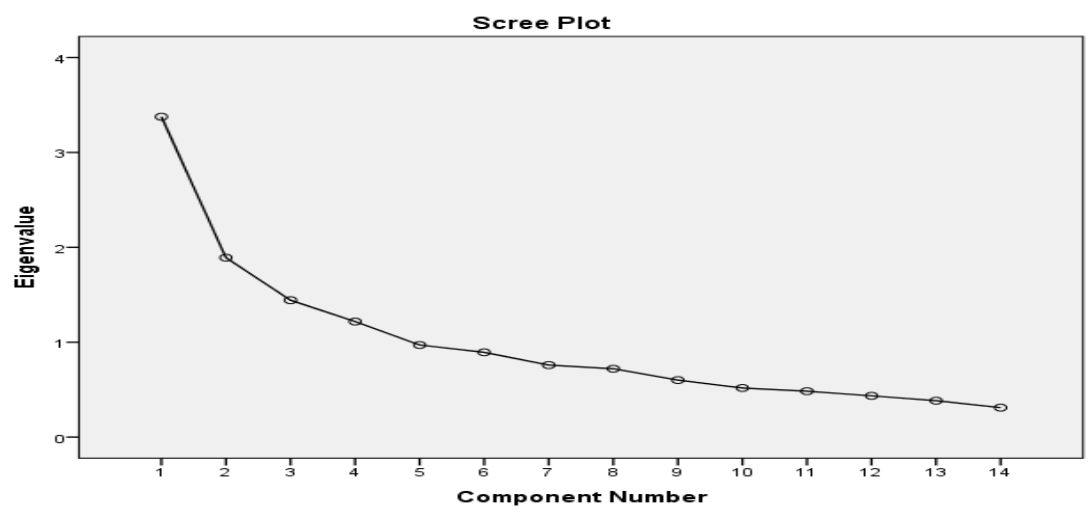

Fig. 1. Screen plot of the extracted factors and the level of their eigenvalue.

Based on the Table II, the first factor labeled as "access to social media" comprises of four items which indicate the kind of technological devices (computer, phone or IPad) students use to get access to internet and download or upload pictures and videos. The reliability of the factor is $a=0.711$ which is satisfactory. The second factor also consists of four items named as "academic communication" it indicates students" academic communication through social media. The factor also has a satisfactory reliability with $a=.0709$. Contrarily to the first and second factors, the third factor constitutes three items titled as "exposure" it describes students' disclosure on social media as they view them as network sites where they feel free to share their ideas, feelings to others and use to improve their academic activities. The reliability of the factor is also satisfactory $a=.072$. Similar to the third factor, fourth factor has also three items. The factor named "academic attainment" it reveals students' perception on social media as a means for academic achievement. It is found that, the 
students have positive perception on social media as they perceive that using social media improve their academic achievement. The reliability of the factor is $a=.0704$, which is also satisfactory like the other three factors. Fig. 1 provides graphic representation of Eigen values and it guide to the determination of the number of the essential Factorial Axes Analysis.

\section{CONCLUSION}

The main objective of this study is to examine psychometric properties of the Social Media and Academic Influence Scale (SMAIS) by giving emphasis in determining the construct validity of the instrument. The findings revealed that the most commonly used social media among students in the university are Facebook and Whats App. This finding is similar to that of [5] who found that Facebook is one of the most accessible and usable social media used by the students of Higher Learning Institutions. This is because Facebook as well as other social media require less kills to be assessed and affordable to many students. In addition, it was found that students used the social media for different purposes which comprises of Educational, Informational and communicational reasons. In this research most of the students use social network for educational and informational purpose. This is contrary to the findings of [4] that majority of students of University of New Hampshire use social networking for social connections and entertainment, but is also using it for education and professional reasons.

On the other hand, the exploratory factor analysis provides four main constructs labeled as access to social media, academic communication, exposure and academic attainment. The psychometric properties of the instruments were adequate with indicators such as variance explained, communalities, anti-image, rotated component matrix and Eigen values for each of the respective construct. The adequacy of the psychometric properties justifies that the instrument has successfully passed exploratory stage, indicating that the instrument is ready to be subjected to further analysis.

\section{REFERENCES}

[1] S. Brown, "From VLEs to learning webs: The implications of Web 2.0 for learning and teaching," Interactive Learning Environments, vol. 18, no. 1, pp. 1-10, 2010.

[2] A. Schroeder, S. Minocha, and C. Schneider, "Social software in higher education: The diversity of applications and their contributions to students' learning experiences," Communications of the Association for Information Systems, vol. 26, pp. 547-564, 2010.

[3] D. A. Ellison, "Social network sites: Definition, history, and scholarship," Journal of Computer-Mediated Communication, pp. $1-11,2007$

[4] C. S. Nicole, "The benefits of facebook 'fiends;' social capital and college students' use of online social network sites," Journal of Computer-Mediated Communication, vol. 1, pp. 27-44, 2007.

[5] A. Boyd, Self-Efficacy: The Exercise of Control, Worth Publishers, 2007.

[6] Anonymous, Student Grades Not Affected by Social Networking, University of New Hampshire, 2010.

[7] W. Kist, I Gave up My Space for Lent: New Teachers and Social Networking Sites, 2008.

[8] K. Flad, The Influence of Social Networking Participation on Student Academic Performance Across Gender Lines, 2010.

[9] I. A. Qazi, "A look out for academic impacts of social networking sites (SNSs): A student based perspective," African Journal of Business Management, pp. 5022-5031, 2011.

[10] M. Robin and R. Frank, The Connecticon: Learning for the Connected Generation, USA: Information Age Publishing, 2004.

[11] L. Cohen, L. Manion, and K. Morrison, Research Methods in Education, London, Routledge, 2011.

[12] J. W. Cresswell, Educational Research: Planning, Conducting, and Evaluating Qualitative and Quantitative Research, New Yourk, Pearson, 2012.

[13] J. Mehmood and K. Taswir, "The effect of social networking sites on the academic performance of students in college of applied sciences Nizwan, Oman," International Journal of Arts and Commerce, vol. 1, no. 1, pp. 111-125, 2013.

[14] J. Pallant, A Step-by-Step Guide to Data Analysis Using SPSS, Open University Press, Maidenhead, 2007.

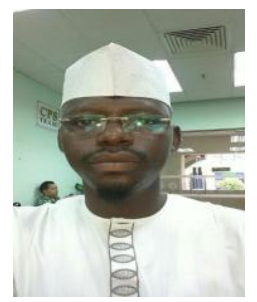

Ahmad Abdullahi Ibrahim was born in Kano, Nigeria on September 19, 1986. Ibrahim is a PhD candidate in the field of instructional technology in International Islamic University, Malaysia (IIUM) from 2015 to date. From 2010 to 2012, he obtained a master degree in instructional technology), from IIUM. In 2008, he obtained his first degree in education and Islamic studies from Bayero University, Kano. Ibrahim held various responsibilities and positions. Besides, he published many articles in both local and international journals such as International Journal of Social Sciences and Education, and Kano Journal of Educational Studies. 